\title{
The economics of negative interest rates
}

\author{
Thomas I. Palley \\ Independent analyst, Washington, DC, USA \\ Louis-Philippe Rochon \\ Professor of Economics, Laurentian University, Sudbury, ON, Canada \\ Guillaume Vallet \\ Associate Professor of Economics, University of Grenoble Alpes, France
}

The Great Recession (2008/2009) triggered by the global financial crisis of 2008 has had considerable impact on the conduct of monetary policy. Before the recession, monetary policy was largely based on a New Consensus-type macroeconomic model and it targeted inflation via a Taylor interest-rate rule. The belief was that policy engineered changes in real interest rates had strong and predictable effects on output and inflation.

Based on that understanding, in the immediate wake of the financial crisis, central banks were quick to lower their policy interest rate to zero or near zero. The expectation was for a speedy and robust V-shaped recovery, an expectation which was reflected in Federal Reserve Chairman Ben Bernanke's comments in March 2009 about seeing 'green shoots' of economic recovery.

When that V-shaped recovery failed to materialize, expectations shifted to a U-shaped recovery, and then in turn morphed into L-shaped recovery and talk of secular stagnation. Those developments prompted central banks to adopt what Mervyn King, Governor of the Bank of England, termed 'unconventional measures.' First came quantitative easing (QE) in 2008, which was initially a policy to contain the financial crisis, but then became a policy for combatting the disappointing recovery. After that, in late 2014, came the adoption of negative interest-rate policy (NIRP).

The turn to NIRP reflects the breakdown of the macroeconomic model that guided monetary policy in the decade before the Great Recession. For central bank and mainstream economists the challenge has been to explain that breakdown, and it has given rise to zero lower bound (ZLB) economics. The argument is the Great Recession caused the natural rate of interest to become negative, but the ZLB on nominal interest rates prevented the market from delivering that required interest rate. Consequently, policy was compelled to step in with NIRP to overcome the ZLB obstruction.

For Keynesians and Post-Keynesians, the adoption of NIRP raises fundamental theoretical and policy questions. With regard to theory, there is the fundamental question of whether negative interest rates increase aggregate demand (AD). That, in turn, raises the question of whether there exists a natural rate of interest (that is, an interest rate that delivers $\mathrm{AD}$ equal to full employment output). With regard to policy, there are questions about possible adverse consequences of negative interest rates, and whether there are superior policy modalities for addressing the problem of AD shortage.

The papers in this symposium address those questions and explore the reasoning and implications of negative interest-rate policy.

Though the global economy has significantly recovered over the past ten years, tilting interest rates in an upward direction, in our opinion the issue of negative interest rates has not gone away. Nominal and real interest rates both remain very low by recent 
136 Review of Keynesian Economics, Vol. 7 No. 2

historical standards, and it is highly likely that NIRP will be back on the policy agenda in the event of renewed recession in developed economies.

For all the above reasons, we believe a symposium on the economics of negative interest rates is timely, relevant, and important. We hope it fosters dialogue with central bank economists, thereby contributing to the incorporation in monetary policy of Keynesian thinking on these issues. 